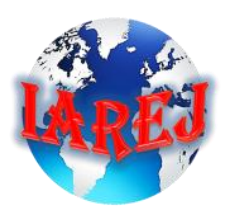

Available online at www.dergipark.gov.tr

INTERNATIONAL ADVANCED RESEARCHES

and

ENGINEERING JOURNAL

Research Article

\title{
Determination of heat transfer coefficient and electromagnetic directional analysis of pomegranate seed
}

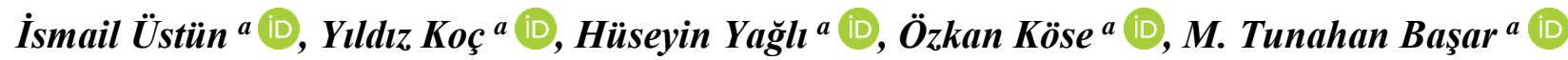

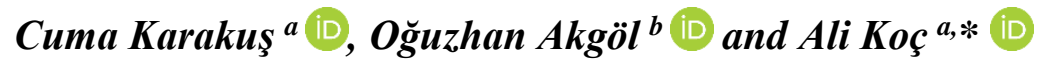

${ }^{a}$ Department of Mechanical Engineering, Iskenderun Technical University, Iskenderun, Hatay, 31200, Turkey

${ }^{b}$ Department of Electrical Engineering, Iskenderun Technical University, Iskenderun, Hatay, 31200, Turkey

\begin{tabular}{l}
\hline ARTICLE INFO \\
\hline Article history: \\
Received 03 April 2018 \\
Revised 11 April 2019 \\
Accepted 12 July 2019 \\
\hline Keywords: \\
Insulation materials \\
Thermal conductivity coefficient \\
Electromagnetic field permeability \\
Energy saving
\end{tabular}

\begin{abstract}
As Turkey uses about $25.7 \%$ of energy consumption in residential area and doing this with natural gas imported from the abroad, production of efficient insolation materials is important to decrease energy dependence and deficiency. Due to both waste minimisation and money saving, there are great efforts on developing new environment friendly insulation materials. In the scope of the current study, the heat transfer coefficient was acquired by applying the linear heat conduction coefficient measurement device to find the heat transfer coefficient of the pomegranate seed sample obtained from various processes for the production of insolation material. The sample also have been examined with a two-port vector network analyser to see electromagnetic property. At the end of the experiment, the heat transfer coefficient of the sample produced from pomegranate seeds was calculate as $\mathrm{k}=0.6115 \mathrm{~W} / \mathrm{mK}$. Moreover, it has been found that the obtained sample performs better than the other insulation materials in terms of electromagnetic perspective. With this feature of the sample, it has been found that using as insolation material in the areas with the high electro-magnetic field can minimize the effect of the harmful electromagnetism in the place where it is applied.
\end{abstract}

\section{Introduction}

The fast increase of world population and industrialization have caused incredible energy demand all over the world. Total primary energy consumption is $150,000,000 \mathrm{GWh}$ and it is estimated to rise by $57 \%$ until the year 2050 These energy consumptions depend on fossil fuels such as petroleum, natural gas and coal [1-2]. As a result of the utilization of these limited energy resources as energy, there have been many undesirable effects such as the deterioration of ecological balance, climate change and accumulation of greenhouse gases on the ozone layer [3].

The wold needs more energy day by day because of increasing population and industrialization and this reached 13,147 billion tons of oil equivalent (TOE) and this energy consumption for Turkey is around 126,9 million (TOE) by end of the 2015 [4,5].

Turkey's energy production, that is totally 148.491 thousand (TOE) and only 35.374 thousand (TOE) with domestic resources in 2016, is not enough to meet increasing energy needs from local sources especially for natural gas and oil [4- 6]. In order to meet these energy needs, Turkey import great amounts of energy from the other countries [7-4]. Turkey's energy dependence rate has started to rise especially since the early 1990 and continue around $70 \%$ since the early 2000 s [8]. Turkey needs to use its abundant renewable energy to decrease its energy dependence and develop domestic production rather than export [9] in all sector such as isolation materials, food and the important part of renewable energy technologies. In addition to these, increasing the continuity and efficiency of existing systems in industry is important for energy sector and for its planning [10-13].

* Corresponding author. Tel.: +90 (326) 6135600 ; Fax: +90 (326) 6135613.

E-mail addresses: ismail.ustun@iste.edu.tr $(\dot{I} . \ddot{U}$ Ustün), yildiz.koc@iste.edu.tr $(Y$. Koç), huseyin.yagli@iste.edu.tr $(H$. Yağll), ozkan.kose@iste.edu.tr $(\ddot{O}$. . Köse), mustafabasar12@hotmail.com (M.T.Başar), cuma.karakus@iste.edu.tr (C.Karakuş), oguzhan.akgol@iste.edu.tr (O.Akgöl), ali.koc@iste.edu.tr (A. Koç) ORCID: 0000-0001-8885-5510 (İ. Üstün), 0000-0002-2219-645X (Y. Koç), 0000-0002-9777-0698 (H. Yağll), 0000-0002-9069-1989 (Ö. Köse), 0000-0002-3108-8995(M.T. Başar), 0000-0002-3553-9335 (C. Karakuş), 00000002-1423-1569 (O. Akgöl), 00000002-7388-2628 (A. Koç) DOI: 10.35860 /iarej.412270 
Considering $25.7 \%$ of residential energy consumption of Turkey which imports a large portion of its energy needs, it is very important to develop isolation materials technologically and decrease their costs [14]. As the technological development is increase, energy demand of the world increases parallelly and alternative energy sources have been taken an importance place such as renewable energy [15].

Because the technological advancements in insulation materials take place, lighter and ergonomic materials can be produced. Thus, loss of life and damage to buildings can be reduced in case of an earthquake. Because natural resources are limited and consumption is increasing rapidly, recycling has been one of the important issues discussed in the world lately [16]. Thanks to the recycling efforts, wastes in many sectors (marble pieces, paper, metal beverage boxes, etc.) can be recovered many times and used with less cost and labour power. Efforts in the world where existing energy resources are using cost effective and efficient way are constantly increasing. However, Studies and operation on recycling in agricultural areas are still insufficient and limited. The recycling of agricultural product and the conversion of lost biological waste into workable forms in different industrial will bring along important development. According to Food and agriculture Organization of the United Nation, 1.3 billion tons of waste from food is takes place per year globally [17]. During Industrial process of organic waste like pomegranate seed, huge volume of this wastes are accumulated, the proportion of which affects the environment badly [18].

In the sense of protecting the energy, the use of these wastes as insulation materials is going to increase the sustainability as well as the energy savings in the world. A number of studies have been conducted on recovery of waste materials.

Dönmez at al. have indicated that the tree bark in our country contains chemically different substances and have worked on its recycling into industry. They have emphasized the importance of increasing the use of wood crusts in different areas such as concrete strengthening, sound insulation and heat insulation in the industrial areas [19].

Ozkan et al. have studied the change in the thermal conductivity of the concrete with the addition of graphene [20].

Binici at al. analysed the heat, sound and radiation transmittance of chipboard panels produced by cotton wool, fly ash and barite. In the experiment of heat insulation, they found the heat transfer coefficient at around $0.0023 \mathrm{~kW} / \mathrm{mK}$ (containing textile waste) and stated the light building materials and thermal insulation material. They found a better sound insulation in the sample with the textile waste and examined the insulation properties for the radioactive areas in their formed samples [21]. In the sense of the recycling and energy recovery from insulation materials, Kozak investigated solid waste which is obtained from textile industry and also pointed out the energy saving. They predicted that the applicability of recycling plants in the production of construction and geo-textile equipment can be investigated [22]. Tüccar and Uludamar have studied utilization of pomegranate seed oil biodiesel to find alternative fuel to diesel engine [1].

There are many subjects of study area on pomegranate seed in literature such as; food science and nutrition [23,24], medicine [25] and other areas [26]. As far as literature is examined, we have not encountered much the study about heat conduction coefficient, electromagnetic examination and usability pomegranate seeds as an insulating material.

Mahmoodi and Hosein studied on thermal conductivity of exocarp, mesocarp and seed of pomegranate samples and found heat transfer coefficient between 0.15 to 0.42 $\mathrm{W} / \mathrm{m}^{\circ} \mathrm{C}, 0.15$ to $0.45 \mathrm{~W} / \mathrm{m}^{\circ} \mathrm{C}$ and 0.13 to $0.42 \mathrm{~W} / \mathrm{m}^{\circ} \mathrm{C}$ in Alan and 0.18 to $0.5 \mathrm{~W} / \mathrm{m}^{\circ} \mathrm{C}, 0.2$ to $0.49 \mathrm{~W} / \mathrm{m}^{\circ} \mathrm{C}$ and 0.18 to $0.51 \mathrm{~W} / \mathrm{m}^{\circ} \mathrm{C}$ in Aghamad-ali, under different temperature and humidity condition, respectively [27].

Mukama et al. have studied about thermal properties of whole and tissue parts of pomegranate. They determined the thermal conductivity of aril part, mesocarp and epicarp in Acco at $7{ }^{\circ} \mathrm{C}, 0.419 \mathrm{Wm}^{-1} \mathrm{~K}^{-1}, 0.352 \mathrm{Wm}^{-1} \mathrm{~K}^{-1}, 0.389$ $\mathrm{Wm}^{-1} \mathrm{~K}^{-1}$, respectively [28].

As a result, investigating the recycling of agricultural waste both in the literature and in practice is reasonable and valuable. In this study, the usability of the pomegranate seed as an isolation substance has been investigated. Researches, experiments and analyses were also conducted about the suitability of pomegranate seed which has been passed through some processes, without additive, as an insulation material in industrial and engineering fields.

First of all, the pomegranate seeds that have been separated from the wastes are dried until the biological reactions are finished, and then dried pomegranate seeds are pulverized and pressed in standard heat insulation sample sizes ( 30 x $30 \mathrm{~mm}$ cylindrical form). The pressed samples were then placed in a linear heat transfer coefficient measurement device, coefficient analysis and necessary data were recorded.

Because of the negative effects of electromagnetic radiation, we have been exposed to in almost every part of our lives with developing technology, studies on various types of insulation materials that will prevent electromagnetic radiation are increasing day by day.

In order to determine the electromagnetic characteristics of the proposed sample, measurements were made in the laboratory using with two-port Agilent brand vector network analyser which is capable of operating up to 43 $\mathrm{GHz}$ and also using two high gain, wideband, linearly polarized horn antennas operating in the frequency range of 3-18 GHz. The prepared samples were compared with the existing insulation materials and pure concrete in terms of their electromagnetic properties and their transmission characteristics were also compared with reflection. During measurements, s-parameters, also known as scatter parameters, were measured and found to generate significant differences in the 3-18 GHz frequency band. 
The s-parameter used for reflection is S11, showing how much of the power from the first port is reflected back. In addition, the parameter used for transmission is obtained with S12 measurement. This parameter shows the proportions of the electromagnetic energy transmission between the two ports. When the literature is examined, an electromagnetic measurement of such a wide band gap has not been found, especially for an agricultural waste material of the proposed type.

The purpose of this objective study is to production of alternative materials to insulation materials, regain organic waste to the industry sector and keep the environment from the adverse effect of industrial organic waste. The organic wastes that thrown through the environment was investigated to see recyclability of the waste. Therefore, organic wastes derived from pomegranate was examined. Because, pomegranate one of the main agricultural production of the Iskenderun region, which is commonly uses to produce pomegranate syrup. Due to high pomegranate syrup production capacity of the region, there are so much pomegranate seeds that thrown to the environment.

In the scope of the study, the usability of pomegranate seed, which is one of the most wasted wastes in the region, has been investigated as an insulating material. Firstly, a sample produced from pomegranate seed was prepared to determine heat conduction coefficient. Then, the electromagnetic measurement was applied on the sample to analyse the electromagnetic adsorption behaviour.

\section{Material and Method}

\subsection{Preparing the Sample}

The separated pomegranate seeds were dried under the sun in a specific area until the biological reactions were ended (Figure 1). Dried pomegranate seeds are ground to powder to make them homogeneous. In order to prepare sample form suitable for linear heat transfer coefficient measurement device (30x30 mm cylindrical format), a special stamping mould have been manufactured with lathe and the prepared pomegranate powder were pressed in this mould (Figure 2).

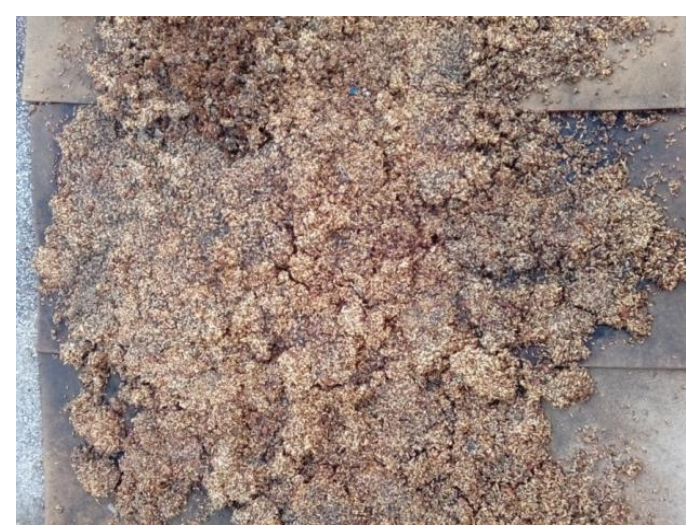

Figure 1. Pomegranate seeds in the drying phase

\subsection{Experimental System}

\subsubsection{Heat Conduction Coefficient Test System}

In this study, the investigation of the sample made from pomegranate seed powder was conducted with our existing heat transfer coefficient measuring device (Figure 3).



Figure 2. The final shape of sample and mould



Figure 3. Experiment Device

The experimental device generally consists of three main parts;

The first is the part of the cooling water through which the cooling water passes and the heat given to the system is removed from the system. In this part, temperatures were measured at three different location in total including the water coming from the cold source, the surface where the water and sample contacted and the temperatures of the heated cooling water after the contact.

The second and the main part is the location where the sample is placed. A total of three temperature measurements are made on the sample. These are the surface temperature of the sample on the refrigerant side, the temperature of the midpoint of the sample and the surface temperatures at which the sample contacts the hot source.

The third is the hot zone within the resistance that provides heat to the system. In the heating zone, a total of two temperature measurements are made on the surface and the resistance that the hot source touches to the sample. 


\subsubsection{Electromagnetic Measurement Test System}

The experimental setup used is shown in Figure 4. As can be seen in the figure, the horn antennas are connected to the two-port network analyser and the samples are placed in the mid-point of the antennas. The distance between the two horn antennas is chosen above the limit value in order to measure outside of the near reactive field region.

Table 1. The Technical Specifications of Heat Conduction Coefficient Test System [29]

\begin{tabular}{|c|c|c|}
\hline Measuring Ability & $\begin{array}{l}\text { Linear and } \\
\text { Radial }\end{array}$ & - \\
\hline $\begin{array}{c}\text { Number of Measuring } \\
\text { Sensor }\end{array}$ & 15 & - \\
\hline Linear Heating Capacity & 100 & W \\
\hline Radial Heating Capacity & 100 & W \\
\hline Measurement Range & -20 to 200 & ${ }^{\circ} \mathrm{C}$ \\
\hline Cooling System & Water & - \\
\hline Measurement System & Digital & - \\
\hline
\end{tabular}

The technical specification of heat conduction coefficient test system has been given above in Table 1 .
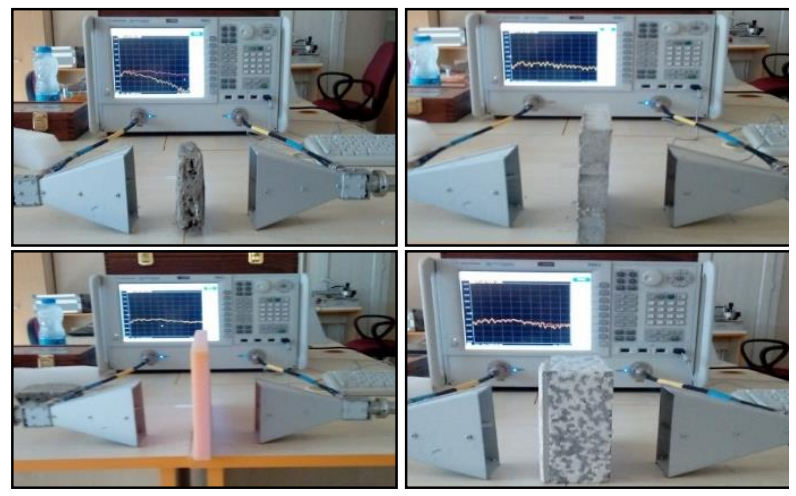

Figure 4. Magnetic measuring device

The device was calibrated over both ports before measurements were started in order to avoid losses that could result from cabling and connection devices. Since the test cables are made up of convolutional cables, the type of calibration set that is suitable for such connections was selected and the calibration was tested, with the open, closed, load states and transmission states carefully adjusted for both ports and also measurement was tested, when the device was idle.

Table 2. The Technical Specifications of the N5234A PNA-L Microwave Network Analyzer Test System

\begin{tabular}{|c|c|c|}
\hline Maximum Frequency & 43.5 & $\mathrm{GHz}$ \\
\hline Dynamic Range & 122 & $\mathrm{~dB}$ \\
\hline Output Power & 6 & $\mathrm{dBm}$ \\
\hline $\begin{array}{c}\text { Number of Built-In } \\
\text { Ports }\end{array}$ & 2 Ports & - \\
\hline Harmonics & -33 & $\mathrm{dBc}$ \\
\hline $\begin{array}{c}\text { Network Analyzer } \\
\text { Series }\end{array}$ & $\begin{array}{c}\text { PNA-L } \\
\text { Economy }\end{array}$ & - \\
\hline Instrument Type & n/a & - \\
\hline
\end{tabular}

The Technical specifications of the N5234A PNA-L microwave network analyser test system used for measuring scattering parameters have been given in Table 2.

\subsection{Formulas and Acceptances}

Heat conduction occurs in three main forms, conduction, convection and radiation.

Since the heat energy lost in the walls is mostly proportional to the heat conduction and the heat conduction coefficient, the transmission through the conduction is examined in this study.

Heat conduction is the transfer of heat from a hot zone to a colder zone. In rigid objects, this occurs via conduction and is theoretically calculated by Fourier's law. Fourier's law basically is described with the equation below.

$$
Q_{x}=-k A \frac{d T}{d x}
$$

Here, $Q_{x}$ is the amount of heat (Watt) that passes vertically through a certain area in the x direction. $k$ and $A$ show heat conduction coefficient $(\mathrm{W} / \mathrm{mK})$ and the area $\left(\mathrm{m}^{2}\right)$, respectively. When the equation is rewritten to leave the heat transfer coefficient alone,

$$
k=\frac{Q L}{A(\Delta T)}
$$

is obtained by the expression. In the test setup, the electrical resistance is used as a heat source and is indicated by the heat (Q) given to the system by the electrical resistance. The air bubbles in the prepared sample during the test and calculations are assumed to be zero. A total of 800 data have been taken from the test device. The average heat transfer coefficient has been calculated by using data at the time, when the lines in the graph flatten.

\section{Research Findings}

\subsection{Thermal Conductivity of Sample}

When the prepared sample is examined in terms of heat conduction in the experimental setup, the graph of the heat transfer coefficient change obtained in the system is given in Figure 5.



Figure 5. Alteration of the heat transfer coefficient 
The data was recorded for every five seconds from the test setup and the recorded data was analysed graphically. When the data taken from the device is examined entirely, it is clearly seen that the heat transfer coefficient value not stable up to $690^{\text {th }}$ data after that the system is seen in balance between $690^{\text {th }}$ and $800^{\text {th }}$, where the values are near to each other and the line started to flatten. Accordingly, the heat transfer coefficient of the pomegranate seed was found as $\mathrm{k}$ $=0.6115(\mathrm{~W} / \mathrm{mK})$ in the tests conducted under the above and on accepted conditions. There are little studies on heat transfer coefficient of pomegranate seed in literature and they found smaller heat condition coefficient than $\mathrm{k}=0.6115$ $(\mathrm{W} / \mathrm{mK})$ in theirs studies. The pomegranate seed sample that used in the experiment setup was made into a single piece by pressing with a cylindrical mold. However, in other studies $[27,28]$, the pomegranate seed sample was milled and dried to measure at different humidity and temperature in test tube without being pressed. In contrast to the pressed sample, when the measurement is made in this way, air molecules fill the gaps of the sample and cause the heat transfer coefficient to be smaller.

In addition, since the heat transfer coefficient of the pomegranate seed is smaller than the pure concrete $(\mathrm{k}$ concrete $=8 \mathrm{~W} / \mathrm{mK}$ ) [30], it makes alternative to the concrete for using an insulation material in structure and even in insulation reinforced concrete buildings.

\subsection{Electromagnetic Measurement}

Experimental studies of the electromagnetic transduction of the sample were completed using a two-port vector network analyser device. This device offers S-parameters, also known as scattering parameters. Insulation materials such as carbon reinforced Eps (Expanded Polystyrene), Sponge and 18 densite Eps (Styrofoam) were compared with the concrete with added pomegranate seed for their heat transfer coefficients. At the beginning of the measurement, the device is calibrated and the effect of the added cables, adapters, equipment, etc. is eliminated. The values of the scattering parameters in the frequency range of 3-18 GHz band are shown in Figure 6 and Figure 7. The pomegranate sample was compared with the commonly used insulation materials under the same laboratory conditions.

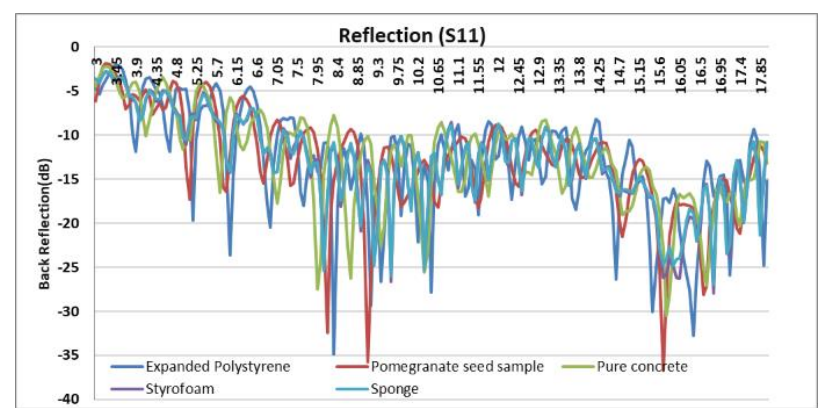

Figure 6. Alteration of reflection parameter according to frequency $(\mathrm{GHz})$

When the variation of the reflection parameter is examined, it appears that the sample does not have a meaningful effect on the reflected signal at this time. However, examining Figure 7, which shows the energy transfer from the first port to the second port (or vice versa), the proposed sample clearly showed significant differences, especially after $6 \mathrm{GHz}$. As the values in the graph become smaller, it shows that the energy transfer between the ports decreases by that amount in $\mathrm{dB}$. One can see from the figure that the proposed structure preventing the electromagnetic energy transfer and behaves like an electromagnetic absorber. Considering that there is not too much return, it appears that the sample is absorbing the signal in the frequency band being worked on. Because of this feature, the use of the proposed sample as an insulation material will provide many benefits;



Figure 7. Alteration of Transmission Parameter according to frequency $(\mathrm{GHz})$

\section{Conclusions}

In this study; a new perspective on the recovery of agricultural wastes with limited use in the industry has been put forward. It is an important fact that a great amount of energy saving can be made by performing recycling of the wastes obtained in the sectors especially in agricultural areas and this energy saving has a great importance. In this experimental study conducted about the recovery of tons of pomegranate seeds which are thrown as agricultural wastes, the heat transfer coefficient obtained from these pomegranate seeds are measured $(\mathrm{k}=0.6115 \mathrm{~W} / \mathrm{mK})$. This heat transfer coefficient value indicates that the use of pomegranate seed as thermal insulation material is alternative to concrete because of better heat transfer coefficient. It has been shown that it might be possible to use it as an additive material to other insolation. In addition, it has been found at the end of the conducted electromagnetic measurements that the proposed material offers considerable advantages in terms of electromagnetic insulation compared to the existing insulation materials and pure concrete. Although the reflection values did not alter much, the transmitted power was identified to decrease at very high rates especially after the frequency of $6 \mathrm{GHz}$, and it is believed that it can be advantageous to use it as an electromagnetic absorber. In today's environment, where electromagnetic radiation is very common, especially near to base stations and other places where electromagnetic pollution is high, the use of such insulating materials will provide a lot of advantages. Consequently, in the case of using electromagnetic absorption materials such as the test sample can absorb undesirable effect of the electromagnetic radiation especially in closed structures such as houses, schools, hospitals etc. 


\section{Nomenclature}

$Q \quad$ : Heat quantity (W)

$k \quad$ : Heat transfer coefficient $(\mathrm{W} / \mathrm{mK})$

$T \quad$ : Temperature (K)

A : Area $\left(\mathrm{m}^{2}\right)$

$l \quad$ : Thickness (m)

\section{References}

1. Tüccar, G. and Uludamar, E., Emission and engine performance analysis of a diesel engine using hydrogen enriched pomegranate seed oil biodiesel. International Journal of Hydrogen Energy, 2018. 43(38): p. 18014-18019.

2. Hajjari, M., Tabatabaei, M., Aghbashlo, M., and Ghanavati, H., A review on the prospects of sustainable biodiesel production: a global scenario with an emphasis on wasteoil biodiesel utilization. Renewable and Sustainable Energy Reviews, 2017. 72: p. 445-464.

3. Bulut, U., and Muratoglu, G., Renewable energy in Turkey: Great potential, low but increasing utilization, and an empirical analysis on renewable energy-growth nexus. Energy Policy, 2018. 123: p. 240-250.

4. Koç, A., Yağlı, H., Koç, Y., and Uğurlu, İ., Dünyada ve Türkiye'de Enerji Görünümünün Genel Değerlendirilmesi. Engineer \& the Machinery Magazine, 2018. 59(692): p. 86114.

5. Türkiye Doğalgaz Dağıtıcıları Birliği (GAZBİR), [cited $201909 \quad$ February]; Available from: http://www.gazbir.org.tr/uploads/page/Dunya-ve-TurkiyeEnerji-Gorunumu.pdf

6. Enerji Tabii ve Kaynaklar Bakanlı̆̆1. [cited 201909 February]; Available from: https://www.eigm.gov.tr/trTR/Denge-Tablolari/Denge-Tablolari.

7. Bulut, U. and Muratoglu, G., Renewable energy in Turkey: Great potential, low but increasing utilization, and an empirical analysis on renewable energy-growth nexus. Energy Policy, 2018. 123: p. 240-250.

8. Türkiye Petrolleri (TP). [cited 201909 February]; Available from:http://www.tpao.gov.tr/tp5/docs/rapor/sektorrapor310 5.pdf.

9. Ervural, B. C., Zaim, S., Demirel, O. F., Aydin, Z. and Delen, D., An ANP and fuzzy TOPSIS-based SWOT analysis for Turkey's energy planning. Renewable and Sustainable Energy Reviews, 2018. 82: p. 1538-1550.

10. Bilgiç, H.H., Yağlı, H., Koç, A. and Yapıc1, A., Deneysel bir organik Rankine Çevriminde Yapay Sinir Ağları (YSA) Yardımıyla Güç Tahmini. Selçuk University Journal of Engineering, Science \& Technology, 2016. 4(1): p. 7-17.

11. Yağl1, H., Koç, Y., Koç, A., Görgülü, A. and Tandiroğlu, A., Parametric optimization and exergetic analysis comparison of subcritical and supercritical organic Rankine cycle (ORC) for biogas fuelled combined heat and power (CHP) engine exhaust gas waste heat. Energy, 2016. 111: p. 923 932.

12. Yagli, H., Koc, A., Karakus, C. and Koc, Y. Comparison of toluene and cyclohexane as a working fluid of an organic Rankine cycle used for reheat furnace waste heat recovery. International Journal of Exergy, 2016. 19(3): p. 420-438.

13. Yağlı, H., Karakuş, C., Koç, Y., Çevik, M., Uğurlu, İ. and Koç, A., Designing and exergetic analysis of a solar power tower system for Iskenderun region. International Journal of Exergy, 2019. 28(1): p. 96-112.
14. Yılmaz, M., Türkiye'nin Enerji Potansiyeli ve Yenilenebilir Enerji Kaynaklarının Elektrik Enerjisi Üretimi Açısından Önemi, Ankara Üniversitesi Çevrebilimleri Derg., 2012. 4(2): p. 33-54.

15. İner, G. and Çağlarer, E., Two countries at same parellel in solar energy productions: USA and Turkey. International Advanced Researches and Engineering Journal, 2018. 2(3): p. 325-329.

16. Gürer, C., Atık Mermer Parçalarının Bitümlü Yol Kaplamalarında Değerlendirilmesi, 2005. Yüksek Lisans Tezi, Afyon Kocatepe Üniversitesi, Fen Bilimleri Enstitüsü, Yapı Eğitimi Anabilim Dalı, Afyon.

17. Gustavsson, J., Cederberg, C., Sonesson, U., Otterdijk, R.van. and Meybeck, A. [cited 201909 February]; Available from: http://www.fao.org/3/mb060e/mb060e00.pdf.

18. Goula, A.M. and Lazarides, H.N., Integrated processes can turn industrial food waste into valuable food by-products and/or ingredients: The cases of olive mill and pomegranate wastes. Journal of Food Engineering, 2015. 167: p. 45-50.

19. Dönmez, İ. and Dönmez, Ş., A Ăaç kabuğunun yapısı ve yararlanma imkanlarl. SDÜ Orman Fakültesi Dergisi, 2013. 14: p. 156-162.

20. Köse Ö., Koç Y., Yağlı H., Üstün İ., Kasap F., Öztürk N.A. and Koç A., Experimental Investigation of Thermal Coefficient of the Graphene Used Concrete. International Advanced Researches and Engineering Journal, (2019). (In Print).

21. Binici, H., Gemci, R., Küçükönder A. and Solak H., Pamuk Attğl, Uçucu Kül ve Barit İle Üretilen Sunta Panellerin Isı, Ses ve Radyasyon Geçirgenliği Özellikleri. Yap1 Teknolojileri Elektronik Dergisi, 2012. 8(1): p. 16-25.

22. Kozak, M., Tekstil Atıklarının Yapı Malzemesi Olarak Kullanım Alanlarının Araştırılması. Yapı Teknolojileri Elektronik Dergisi, 2010. 6(1): p. 62-70.

23. Fayaz, G., Goli, S.A.H., Kadivar, M., Valoppi, F., Barba, L., Calligaris, S. and Nicoli, M.C., Potential application of pomegranate seed oil oleogels based on monoglycerides, beeswax and propolis wax as partial substitutes of palm oil in functional chocolate spread. LWT-Food Science and Technology, 2017. 86: p. 523-529.

24. Talekar, S., Patti, A.F., Singh, R., Vijayraghavan, R. and Arora, A., From waste to wealth: High recovery of nutraceuticals from pomegranate seed waste using a green extraction process. Industrial Crops and Products, 2018. 112: p. 790-802.

25. Hora, J.J., Maydew, E.R., Lansky, E.P. and Dwivedi, C., Chemo preventive effects of pomegranate seed oil on skin tumor development in CD1 mice. Journal of medicinal food, 2003. 6(3): p. 157-161.

26. Tüccar, G. and Uludamar, E., Emission and engine performance analysis of a diesel engine using hydrogen enriched pomegranate seed oil biodiesel. International Journal of Hydrogen Energy, 2018. 43(38): p. 18014-18019.

27. Mahmood, M. and Hosein, K.M., Determination and comparison of thermal conductivity of Iranian pomegranate varieties, in 18th National Congress on food technology: Mashhyad. p. 15-16. 
28. Mukama, M., Ambaw, A. and Opara, U.L., Thermal properties of whole and tissue parts of pomegranate (Punica granatum) fruit. Journal of Food Measurement and Characterization, 2018. 13(2): p. 901-910.

29. Deneysan. [cited 201909 February]; Available from: http://deneysan.com/en/products/heat-transfer/ht-350thermal-conductivity-detecting-training-set/221.

30. Georgia State University. [cited 201909 February]; Available from: http://hyperphysics.phyastr.gsu.edu/hbase/Tables/thren. 